\title{
Structure-Function Relationships of Interleukin-3

\author{
An Analysis Based on the Function and Binding Characteristics of a \\ Series of Interspecies Chimera of Gibbon and Murine Interleukin-3
}

\author{
Kenneth Kaushansky, " Sara G. Shoemaker, * Virginia C. Broudy, " Nancy L. Lin, “ Jeffrey V. Matous, “ Edward M. Alderman, ${ }^{*}$ \\ Jane D. Aghajanian, * Pamela J. Szklut, ${ }^{*}$ Robert E. VanDyke, ${ }^{*}$ Michael K. Pearce," and John S. Abrams" \\ ${ }^{*}$ Division of Hematology, University of Washington, Seattle, Washington 98195; ${ }^{\ddagger}$ Genetics Institute, Cambridge, \\ Massachusetts 02140-2387; and ${ }^{\S}$ DNAX Research Institute, Palo Alto, California 94304
}

\begin{abstract}
IL-3 is a glycoprotein cytokine involved in the hematopoietic response to infectious, immunologic, and inflammatory stimuli. In addition, clinical administration of recombinant IL-3 augments recovery in states of natural and treatment-related marrow failure. IL-3 acts by binding to high affinity cell surface receptors present on hematopoietic cells. To determine the site(s) at which IL-3 binds to its receptor, we analyzed a series of interspecies chimera of the growth factor for species-specific receptor binding and biological activity. The results suggest that IL-3 binds to its receptor and triggers a proliferative stimulus through two noncontiguous helical domains located near the amino terminus and the carboxy terminus of the molecule. To corroborate these findings, we have also mapped the binding epitopes of $10 \mathrm{mAb}$ of human or murine IL-3, and have defined four distinct epitopes. Two of these epitopes comprise the amino-terminal receptor binding domain. A third epitope corresponds to the carboxy-terminal receptor interactive domain, and the fourth epitope, apparently not involved in the interaction of IL-3 and its receptor, lies between these sites. And on the basis of sandwich immunoassays using pairs of these $\mathrm{mAbs}$, the two receptor interactive regions appear to reside in close juxtaposition in the tertiary structure of the molecule. These results provide a correlation of the structure-function relationships of IL-3 that should prove useful in evaluating the details of IL-3-IL-3 receptor interaction and in the rational design of clinically useful derivatives of this growth factor. (J. Clin. Invest. 1992. 90:1879-1888.) Key words: hematopoiesis • amphipathic $\bullet$ epitope $\bullet$ cytokines $\bullet$ multi-CSF
\end{abstract}

\section{Introduction}

IL-3 or multi-colony-stimulating factor $(\mathrm{CSF})^{1}$ is an acidic glycoprotein involved in the survival and self-renewal of hematopoietic stem cells, the proliferation and differentiation of

Address correspondence and reprint requests to Kenneth Kaushansky, M.D., Department of Medicine, Division of Hematology RM-10, University of Washington, Seattle, WA 98195.

Received for publication 24 March 1992 and in revised form 2 June 1992.

1. Abbreviations used in this paper: FICA, Freund's incomplete adjuvant; GM-CSF, granulocyte-macrophage colony-stimulating factor; NHIA, $N$-hydroxysuccinimide ester of iodoacetic acid.

J. Clin. Invest.

(c) The American Society for Clinical Investigation, Inc.

$0021-9738 / 92 / 11 / 1879 / 10 \quad \$ 2.00$

Volume 90, November 1992, 1879-1888 committed progenitors and in the functional activation of mature leukocytes (1-3). In this way, IL-3 is thought to be involved in the host response to noxious stimuli. In addition, recent studies have implicated IL-3 in the pathogenesis of asthma and hypersensitivity (3-5), and in murine and human leukemia (6-8).

IL-3 acts by binding to high affinity cell surface receptors, which are normally present only on cells of hematopoietic lineage $(8,9)$. Recently, low affinity receptors for human and murine IL-3 were cloned $(10,11)$. On the basis of conserved cysteine residues and a five amino acid WSXWS region, the IL-3 receptor was thought to be a member of a growing family of polypeptides that includes the receptors for IL-2, IL-4, IL-5, IL-6, IL-7, granulocyte-macrophage (GM)-CSF, granulocyte CSF, and erythropoietin (12). Based on this homology and receptor cross-linking data, it was proposed that the IL-3 receptor, like the IL-2 and IL-6 receptors, is composed of at least two subunits $(12,13)$. This supposition was recently confirmed by Kitamura et al., who demonstrated that a non-ligand-binding subunit of the human GM-CSF receptor (14) also induces high affinity IL-3 binding when expressed with the low affinity IL-3 receptor (11). This finding has also provided potential mechanisms to explain the reciprocal competition displayed by IL-3 and GM-CSF for binding to cells that bear receptors for both of these cytokines $(13,15,16)$.

Despite its pivotal role in hematopoiesis, little is known of the structural features of IL-3 that are responsible for receptor binding and biological activity. Initial studies using truncated synthetic polypeptides of murine IL-3 suggested that the first disulfide bond and the amino-terminal half of the molecule are responsible for biological activity $(17,18)$. Recently, two groups have reported on the binding sites of neutralizing mAbs of human IL-3 $(19,20)$. Together, 13 mAbs were mapped to residues between $\mathrm{Gln}_{29}$ and $\mathrm{Glu}_{50}$, helping to localize the site of this amino-terminal domain of biological activity. One study has reported on carboxy-terminal truncation mutants of human IL-3 (19). Although the 10 carboxy-terminal residues were dispensable, the activities of more severe truncation mutants were reduced three to four orders of magnitude, making it likely that residues immediately upstream of this position are also involved in receptor interaction.

A number of additional strategies have been used to map the receptor-interactive residues of biologically active polypeptides. Most depend on the activities of internally deleted polypeptides. However, these methods cannot distinguish between loss of activity caused by alterations in secondary or tertiary structure and that caused by loss of a receptor interactive site. Recently, we developed a strategy of substitution mutagenesis based on the structural similarity but biological distinctiveness of the human and murine analogs of a hematopoietic growth 
factor, GM-CSF (21). By generating cross-species chimera and testing them for species specific function, receptor-interactive residues were identified. Human (or gibbon) and murine IL-3 are also species-specific: They do not stimulate the growth of progenitor cells or the function of mature cells from the alternate species, and they do not cross-react at the receptor level. Monoclonal antibodies to human or murine IL-3 also react in a species specific fashion. To further explore the structure-function relationships of IL-3, we used this species specificity to map the sites of receptor binding and biological activity of primate and murine IL-3. Using this approach, two nonlinear sites of IL-3-IL-3 receptor interaction were identified. The first site appears to be sufficient for receptor binding, but inadequate to transmit a proliferative stimulus. The second site is necessary for biological activity. We also show that these two sites correlate with the binding epitopes of several neutralizing mAbs of IL-3, but not with nonneutralizing mAb epitopes. Together, these findings support the hypothesis that the receptor binding domain of IL-3 is composed of at least two elements from distinct regions of the molecule and begin to provide an understanding of the events that lead to a proliferative stimulus in hematopoiesis.

\section{Methods}

Generation of chimeric IL-3 cDNA expression vectors. Full-length cDNA clones for gibbon IL-3 (Dr. Steve Clark, Genetics Institute, Cambridge, MA) and murine IL-3 (Dr. Frank Lee, DNAX Institute, Palo Alto, CA) were subjected to site-directed mutagenesis, as previously described (21), to introduce useful restriction sites or to directly alter the coding sequences (Fig. 1). Recombinant hybrid cDNA expression vectors were produced by ligating restriction fragments of the mutant gibbon or murine IL-3 cDNA into the mammalian cell expression vector pDX $(22)$ by standard techniques. Each mutation and ligation was verified by single-stranded or plasmid DNA sequencing using the dideoxynucleotide chain termination method (23).

Expression of chimeric IL-3 molecules. BHK cells were obtained from American Type Culture Collection (Rockville, MD) and maintained in Dulbecco's MEM supplemented with 5\% FCS and antibiotics. Cells were transfected with the chimeric IL-3 expression vectors and a dihydrofolate reductase (DHFR) expression vector (24) by the calcium phosphate method when $30 \%$ confluent, as previously described (21). After $3 \mathrm{~d}$, the cells were divided and cultured in $250 \mathrm{nM}$ methotrexate. Individual colonies were selected, expanded, and assayed for species-specific IL-3 mRNA expression by slot blot analysis using full-length cDNA clones for gibbon or murine IL-3 labeled by random priming (Multiprime DNA Labeling System; Amersham Corp., Arlington Heights, IL). Cell lines expressing high levels of IL-3-specific RNA were then selected for analysis. To generate biosynthetically ${ }^{35} \mathrm{~S}$-labeled IL-3 molecules, the cell lines expressing chimeric proteins were grown in DMEM devoid of cysteine and methionine, and supplemented with $2 \%$ dialyzed FCS, antibiotics, and 50 $\mu \mathrm{Ci} / \mathrm{ml}^{35} \mathrm{~S}-\mathrm{Cys}+$ Met (Express; New England Nuclear, Boston, MA). The medium was then harvested after 24-36 $\mathrm{h}$.

Quantitative Western blot analysis. The level of specific protein was determined by quantitative Western blotting $(21,22)$. Aliquots of conditioned culture medium from cell lines expressing chimeric IL-3 proteins were denatured, size fractionated through $12 \%$ polyacrylamide gels, transferred to nitrocellulose, and probed with a 1:50 dilution of a rat antiserum raised against a synthetic peptide composed of the 16 amino-terminal residues of human IL-3 (peptide 4, reference 25). Since this antiserum reacts equally well with IL-3 derived from bacterial or mammalian cell expression systems, human IL-3 purified from recombinant Escherichia coli served as a quantitative control. An ${ }^{125} \mathrm{I}$ goat anti-rat Ig antiserum was used to detect immune complexes on the blot. After autoradiography, blots were analyzed by phosphorimaging (Molecular Dynamics, Sunnyvale, CA) to quantitate the amount of ${ }^{125}$ I-detecting reagent present.

Hematopoietic progenitor cell assays. Human marrow cells were obtained from consenting healthy adult volunteers, under a protocol approved by the University of Washington (Seattle, WA). Nonadherent human marrow mononuclear cells were used to assay chimeric IL-3 molecules for their ability to stimulate the growth of granulocytemacrophage colony-forming cells, as previously described (21). The murine IL-3-dependent cell line FDCP1 was obtained from American Type Cuture Collection and was maintained in DMEM with $10 \%$ FCS and $50 \mathrm{U} / \mathrm{ml}$ murine GM-CSF. The FDCP1 cells were used to assess the ability of IL-3 molecules to stimulate murine colony growth, and for murine IL-3 receptor binding assays, as described below. The colony-forming capacity of FDCP1 cells has been shown to correlate precisely with the ability of CSF to stimulate progenitor cell growth from murine marrow cells (26). These results were also confirmed using murine marrow cells, as previously described (21).

Receptor binding assays. The human erythroleukemia cell line OCIM1 (27) was maintained in RPMI 1640 medium supplemented with $10 \%$ FCS and penicillin/streptomycin. 250 pg of ${ }^{125}$ I-human IL-3 (Amersham Corp.) was mixed with $3 \times 10^{5}$ OCIM1 cells in $100 \mu \mathrm{l}$ of binding buffer (RPMI 1640 medium supplemented with $50 \mathrm{mM}$ Hepes [pH 7.4], $1 \% \mathrm{BSA}, 10 \mu \mathrm{g} / \mathrm{ml}$ cytochalasin $\mathrm{B}$, and $0.1 \%$ sodium azide). The mixture also contained human IL-3 (100 ng), murine IL-3 (25 $\mathrm{ng}$ ), or culture medium from cell lines expressing the chimeric proteins ( $10 \mathrm{ng}-19 \mu \mathrm{g}$ ). After a 1-h incubation at $37^{\circ} \mathrm{C}$, cell-bound ${ }^{125} \mathrm{I}$-human IL-3 was separated from unbound ${ }^{125}$ I-IL-3 by centrifuging the cells through phthalate oil (28). For the murine IL-3 receptor assay, $250 \mathrm{pg}$ of ${ }^{125}$ I-murine IL-3 (provided by Dr. Gerry Krystal, British Columbia Cancer Research Center, Vancouver, BC, Canada) was mixed with 7 $\times 10^{5} \mathrm{FDCP} 1$ cells in $100 \mu \mathrm{l}$ of binding buffer (PBS supplemented with $1 \%$ BSA, $0.1 \%$ gelatin, and $0.02 \%$ sodium azide [29]). The mixture also contained unlabeled human or murine IL-3 or the gibbon-murine IL-3 hybrid proteins, as described above. After a 4-h incubation at $4^{\circ} \mathrm{C}$ (29), the cells were centrifuged through phthalate oil. The binding data are expressed as the percentage of competition in the presence of the IL-3 hybrid proteins. The maximal competition achievable with a 100 fold excess of unlabeled human IL-3 in the OCIM1 assay (75\%), or a 100 -fold excess of unlabeled murine IL-3 in the FDCP1 assay (79\%) were defined as $100 \%$ competition. Triplicate measurements were performed in each experiment.

Quantitative receptor binding experiments were also performed using metabolically labeled ${ }^{35}$ S-IL-3. Truncated cDNA that encoded a Met start codon followed by the mature amino acid sequence of gibbon cDNA was subcloned into pBluescript and RNA was transcribed in vitro using $\mathrm{T}_{7}$ RNA polymerase. $2 \mu \mathrm{g}$ of RNA was translated into protein in reticulocyte lysates (Promega Biotech, Madison, WI) in the presence of $\left[{ }^{35} \mathrm{~S}\right] \mathrm{Met}$. The radioactively pure IL-3 was separated from unincorporated label by gel filtration (Sephadex G-25), and the radiologic specific activity of the labeled IL-3 protein was determined by self displacement analysis (30). The amount of ${ }^{35} \mathrm{~S}-\mathrm{IL}-3$ produced in a typical $200 \mu 1$ reticulocyte lysate reaction was $20 \mathrm{ng}$. The ${ }^{35} \mathrm{~S}-\mathrm{IL}-3$ was then used in a receptor binding assay. OCIM1 cells were incubated with varying quantities of ${ }^{35}$ S-gibbon IL-3 (7-330 pM) with or without a 1,000-fold excess of unlabeled IL-3 in binding buffer for $1 \mathrm{~h}$ at $37^{\circ} \mathrm{C}$, as described above. All receptor binding data were analyzed using the LIGAND program (31).

Generation of rat antipeptide IL-3 (human and mouse) monoclonal antibodies. A synthetic oligopeptide [(C) PNLEAFNRAVKSLQNASAI ] corresponding to residues 56-74 of the human IL-3 molecule, was obtained commercially (Applied Biosystems Inc., Foster City, CA). The terminal thiol was used to covalently couple the peptide to sperm whale myoglobin (Sigma Chemical Co., St. Louis, MO), using the heterobifunctional crosslinking reagent $N$-hydroxysuccinimide ester of iodoacetic acid (NHIA) (32). Myoglobin sulfhydryl groups were first blocked by reacting $10 \mathrm{ml}$ of $5 \mathrm{mg} / \mathrm{ml}$ myoglobin in $0.1 \mathrm{M}$ sodium bicarbonate with $1 \mathrm{ml}$ of $0.12 \mathrm{M}$ iodoacetamide (Sigma Chemical Co.) 
for $1 \mathrm{~h}$ at room temperature followed by overnight dialysis against 0.1 $M$ bicarbonate.

A $5 \mathrm{mg} / \mathrm{ml}$ solution of peptide was prepared in $2 \mathrm{ml}$ of $0.1 \mathrm{M} \mathrm{DTT}$, $50 \mathrm{mM}$ Tris, $2.5 \mathrm{mM}$ EDTA, $\mathrm{pH} 8$, and incubated overnight at $37^{\circ} \mathrm{C}$. The reduced peptide was applied to a $1.5 \times 26.5 \mathrm{~cm}$ gel-filtration column (GF 05; LKB Instruments, Inc., Gaithersburg, MD), and was eluted with $15 \mathrm{mM}$ acetic acid, $5 \mathrm{mM} \beta$-mercaptoethanol. Material eluting in the void volume was pooled and lyophilized. The carboxyamidated myoglobin recovered from dialysis was iodoacetylated by reaction with $0.38 \mathrm{ml}$ of $5 \mathrm{mg} / \mathrm{ml} \mathrm{NHIA} \mathrm{in} \mathrm{tetrahydrofuran} \mathrm{for} 30 \mathrm{~min}$ at room temperature with vigorous stirring, followed by dialysis against PBS. The lyophilized peptide was resuspended in $5 \mathrm{ml}$ of $10 \mathrm{mM}$ $\mathrm{Na}_{2} \mathrm{~B}_{4} \mathrm{O}_{7}, 0.29 \mathrm{M} \mathrm{NaCl}, 1 \mathrm{mM}$ EDTA, pH 8.5 (which had been $\mathrm{N}_{2}$ purged for $30 \mathrm{~min}$, followed by addition of $178 \mathrm{mg} / \mathrm{ml}$ ascorbate), and mixed with an equal volume of iodoacetylated myoglobin recovered from dialysis. The conjugation reaction was carried out at room temperature overnight.

A Lewis rat was immunized intraperitoneally with $100 \mu \mathrm{g}$ of peptide-myoglobin conjugate in CFA. The animal was boosted three times with the same peptide conjugate in Freund's incomplete adjuvant (FICA), and splenocytes were fused with P3X63-AG8.653 myeloma cells (American Type Culture Collection) using 50\% polyethylene glycol (33). This fusion resulted in the 8A5 mAb.

The 10F4 rat anti-mouse IL-3 peptide antibody was prepared in a similar fashion using an oligopeptide [(C) VESQGEVDPEDRYVI]ovalbumin conjugate comprising residues 56-70 of mature mouse IL-3 (the analogous residues to those used for human IL-3). This antibody has been previously shown to work in Western blotting, as well as in an indirect ELISA of mouse IL-3 $(34,35)$.

Generation of rat anti-IL-3 (human and mouse) monoclonal antibodies. Two series of fusions with different immunogen forms were carried out to obtain the neutralizing rat anti-human IL-3 antibodies used in this study. In the first fusion, male Lewis rats were immunized with $50 \mu \mathrm{g}$ i.p. yeast expressed-recombinant IL-3 in CFA. Splenocyte fusion with the P3X63-AG8.653 myeloma was carried out $4 \mathrm{~d}$ after the fourth boost. Anti-IL-3 antibody secreting hybridoma were selected on the basis of screening by indirect ELISA on IL-3-coated polyvinylchloride microtiter plates, as well as neutralization of IL-3-induced proliferation of the KG-1 (American Type Culture Collection) myelomonocyte cell line assessed colorimetrically with [3-(4,5-dimethylthiazol-2yl)-2,5-diphenyl tetrazolium bromide] by the method of Mosmann (36). This fusion produced the 1F9 and the 6G8 antibodies.

A subsequent fusion was carried out using glutaraldehyde crosslinked (37) yeast-expressed IL-3 to produce antibodies recognizing different epitopes, as well as more potent neutralizing activity. Yeast-expressed IL- 3 was concentrated to $0.2 \mathrm{mM}$ by Centricon 10 ultrafiltration in PBS, $0.01 \%$ Tween 20 (Sigma Chemical Co.). Glutaraldehyde (Sigma Chemical Co.) was added to a final concentration of $2 \mathrm{mM}$ (10:1 M glutaraldehyde/cytokine). The reaction was incubated for $1 \mathrm{~h}$ at room temperature, then quenched with $\mathrm{L}$-lysine (final concentration $0.1 \mathrm{M}$ ) for an additional hour at room temperature and stored at $4^{\circ} \mathrm{C}$. Male Lewis rats were immunized intraperitoneally with cross-linked IL-3 in CFA. Animals were boosted twice with cross-linked IL-3 in FICA, and then with IL-3 in PBS before splenocyte fusion. Anti-IL-3 antibody-secreting hybridoma were selected based on inhibition of IL3-dependent proliferation of the multifactor TF-1 erythroleukemic cell (38). This fusion produced the 3G11 antibody.

The development and characterization of the neutralizing rat antimouse IL-3 monoclonal antibodies 8F8, 19B3, and 43D11 have been previously described (33). These mAbs exclusively recognize human (and gibbon) or murine IL-3, including that made in E. coli and Saccharomyces cerevisiae expression systems.

Generation of mouse anti-human IL-3 monoclonal antibodies. Five BALB/CJ-Bailey mice (Jackson Laboratory, Bar Harbor, ME) were immunized with recombinant human IL-3 (rhIL-3) by $4 \times 1 \mathrm{ml}$ injections (4-5 sites/injection) at 2-wk intervals, as $50 \%$ ( vol/vol) emulsions of $25,12.5,6.25$, and $6.25 \mu \mathrm{g}$, respectively, in CFA (for first injection) or FICA (Gibco Laboratories, Grand Island, NY). Mice were then rested for $4 \mathrm{wk}$ and challenged by injection of $50 \mu \mathrm{g}$ i.p. adjuvant-free rhIL3 on each of $4 \mathrm{~d}$ before fusion. Immune splenocytes from one of the immunized mice were fused to P3X63AG8.653 murine myeloma cells (1:4 ratio) by standard polyethylene glycol-mediated cell fusion procedures, and plated in 96-well tissue culture plates at a density of $5 \times 10^{5}$ cells/well in standard hypoxanthine aminoprotein thymidine selection medium. Resulting subcultures were fed ad lib, and conditioned medium samples were collected on day 14 (postfusion) for primary screening by RIA ( 18 positive/672 tested) and ELISA ( 33 positive/672 tested). 12 subcultures were selected for further study, each of which was subjected to three rounds of subcloning by limiting dilution ( 0.4 cells/well), resulting in the establishment of 12 hybridoma cell lines, including mAbs 4.4 .7 and 2.6.23.

Binding characteristics of anti-IL-3 mAbs. To determine the capacity of the anti-human IL-3 mAbs to bind to denatured protein, Western blots were prepared using recombinant human IL-3 produced in $E$. coli. After transfer, the blots were denatured and reduced with $20 \%$ methanol and $30 \mathrm{mM} \beta$-mercaptoethanol at $80^{\circ} \mathrm{C}$ for $30 \mathrm{~min}$ and then iodoacetylated with $30 \mathrm{mM}$ iodoacetic acid in the dark at $20^{\circ} \mathrm{C}$. This step was included to make certain that the transferred proteins were fully denatured before detection with each $\mathrm{mAb}$.

Immunoprecipitation of metabolically labeled IL-3 proteins. $1 \mathrm{ml}$ of ${ }^{35} \mathrm{~S}-\mathrm{Met} /$ Cys-labeled conditioned culture medium was mixed with $10 \mu \mathrm{g}$ of affinity-purified antibody or $100 \mu \mathrm{l}$ of monoclonal antibody ascites fluid (8A5 and $10 \mathrm{~F} 4)$ and incubated for $4-16 \mathrm{~h}$ at $4^{\circ} \mathrm{C}$. For the rat $\mathrm{mAbs}, 20 \mu \mathrm{g}$ of anti-rat $\operatorname{Ig}$ (Cappel Laboratories, Cochranville, PA) was added for $3 \mathrm{~h}$ at $4^{\circ} \mathrm{C}$. For the murine $\mathrm{mAb}$, rabbit anti-murine Ig was used, and both sets of immune complexes were precipitated with Staph A (Pansorbin; Calbiochem Corp., La Jolla, CA ) (39). Immunoprecipitates were size fractionated on $12 \% \mathrm{NaDodSO}_{4}$ polyacrylamide gels, the gels were fixed, soaked in Amplify solution (Amersham Corp.), dried, and exposed to film for 2-20 d.

Identification of antibody pairs recognizing spatially distinct epitopes on human IL-3. An immunoenzymetric assay format was used to identify antibody pairs recognizing spatially distinct epitopes on the IL-3 molecule. Polyvinylchloride " $U$ " bottom microtiter plates were coated with $10 \mu \mathrm{g} / \mathrm{ml}$ in $\mathrm{PBS}$ for $2 \mathrm{~h}$ at $37^{\circ} \mathrm{C}$ with various rat monoclonal anti-IL-3 antibodies. These were produced in vitro in HB 102 medium and purified by $66 \%$ saturated ammonium sulfate precipitation and AcA44 gel filtration chromatography, essentially as described (40). Plates were washed (three cycles) between all steps with salineTween 20. Serial dilutions of IL-3 (a 100- $\mu$ l vol in RPMI, 15\% fetal bovine serum containing $40 \mathrm{ng}-5 \mathrm{pg} / \mathrm{ml}$ ) were incubated for $2 \mathrm{~h}$ at room temperature. Nitro-iodophenyl (NIP)-conjugated anti-IL-3 mAbs were prepared by reacting $1 \mathrm{mg} / \mathrm{ml}$ IgG in PBS with $10 \mu \mathrm{l}$ NHIA $(5 \mathrm{mg} / \mathrm{ml}$ in DMSO) for $1 \mathrm{~h}$ at room temperature, followed by overnight dialysis against PBS. NIP-labeled antibodies ( $100 \mu \mathrm{l}$ of $1 \mu \mathrm{g} / \mathrm{ml}$ in PBS/BSA / Tween 20) were incubated in all wells. A rat IgG1 anti-NIP (J4) monoclonal antibody conjugated to horseradish peroxidase was used to detect NIP-anti-IL-3 binding to sites other than those occupied by the coating antibody. 2,2'-azino-bis (2-ethylbenzthiazoline-6-sulfonic acid) was used as chromagen.

Computer analysis. A software package provided by IntelliGenetics (Mountain View, CA) called PC/Gene was run on an IBM PC/ 2 computer. The secondary structure algorithms of Garnier (41), Parry (42), Chow and Fasman (43), and Gascuel (44) were used to predict $\alpha$-helical structure and the program Helwheel was used to determine the presence of amphipatic helixes.

\section{Results}

Chimeric IL-3 protein-producing cell lines. After cotransfection of expression vectors encoding DHFR and the chimeric and mutant proteins illustrated in Fig. 1, cell lines resistant to methotrexate were analyzed by Northern blot analysis using full-length cDNA probes for gibbon IL-3 and murine IL-3. Cell lines that produced RNA that hybridized to the appropriate 


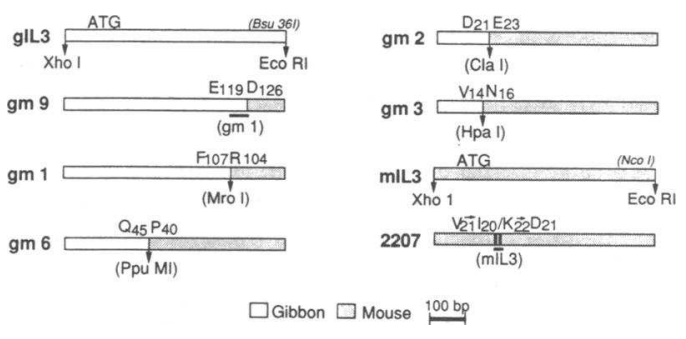

Figure 1. Gibbon-murine chimera. The maps for each of the chimera are shown, along with the methods of construction from the parental vectors $\mathrm{pDgIL3}$ and $\mathrm{pDmIL3}$. Sequences derived from gIL3 are represented by open bars, while sequences specific for murine IL-3 are shown in hatched bars. Restriction sites introduced by mutagenesis are shown in parentheses below each map, and regions mutated directly are underlined with a solid bar along with the construct from which they were derived.

cDNA probes were tested for specific protein production by Western blotting (Fig. 2). As the primary antiserum was directed against a region shared by all of the gibbon-murine IL-3 chimera, the amount of an ${ }^{125} \mathrm{I}$-labeled detecting antibody bound to each protein (determined by phosphorimaging analysis) provided a quantitative measure of the IL-3 protein present in each supernatant (purified recombinant human IL-3 provided a quantitative standard). The variable $M_{\mathrm{r}}$ of the chimera is characteristic of heterogenous levels of glycosylation, a pattern noted in a number of previous studies of hematopoietic growth factors $(21,22,35)$.

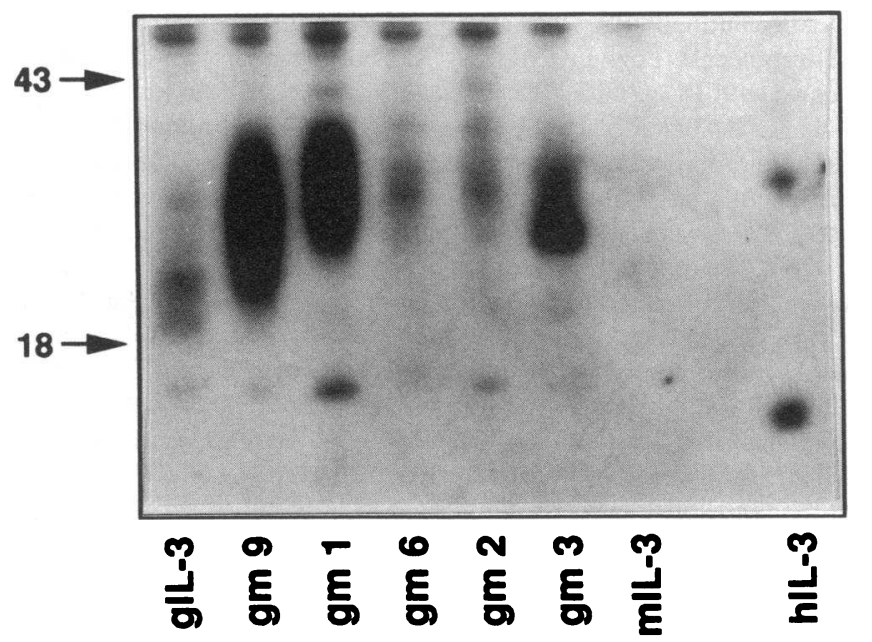

Figure 2. Chimeric cell lines and proteins. BHK cells cotransfected with chimeric IL-3 cDNA expression vectors and a DHFR ${ }^{\mathbf{R}}$ vector (24) were selected in methotrexate and analyzed by quantitative Western blotting. Cell lines that expressed high RNA levels (by slotblot analysis, not shown ) were grown to confluence and conditioned culture medium collected. $60-\mu \mathrm{l}$ aliquots of conditioned culture medium from each cell line and $100 \mathrm{ng}$ of $E$. coli human IL-3 were sizefractionated on a $12 \%$ polyacrylamide gel, transferred to nitrocellulose, and probed with a rat antiserum directed against the amino-terminal 16 residues of human IL-3 (antipeptide 4, reference 25). After incubation with a ${ }^{125}$ I-labeled goat anti-rat Ig antiserum, autoradiography and phosphorimaging was performed. In this experiment, $60 \mu \mathrm{l}$ of BHK gIL 3 conditioned medium contained $500 \mathrm{ng}$ protein; BHK gm 9, 3,000 ng protein; BHK gm 1, 2,000 ng protein; BHK gm 6, 400 ng protein; gm 2, $430 \mathrm{ng}$ protein; and gm 3, 1,030 ng protein.
The biologic activity of chimeric IL-3 proteins. Serial dilutions of the chimeric IL-3-conditioned culture media were assayed for biologic activity in colony-forming assays using human or murine marrow cells (Table I). Together with the quantitative analysis from the Western blot experiments, the specific activities of each chimeric growth factor (relative to native human or murine IL-3) were determined. Beginning from the amino terminus, chimeric protein gm 3 was nearly fully active using murine assays. As expected from the speciesspecificity of gibbon and murine IL-3, gm 3 failed to stimulate human progenitors to form hematopoietic colonies. Because of the sequence homology between gibbon and murine IL-3 in residues 16-22, chimeric protein gm 2 represents a five-amino acid substitution mutant of gm $3\left(L_{15}\right.$ to $V_{14}$ and SIVK $_{22}$ to $\mathrm{NMID}_{21}$ ). The presence of these changes alone resulted in the nearly complete inactivation of chimeric gm 2 in the murine marrow cell proliferation assays (Table I).

To further investigate the importance of residues in this region, an additional double substitution mutant termed 2207 was analyzed. As shown in Fig. 1, the 2207 mutant contains an Ile-Asp dipeptide at positions 21 and 22 in place of the wild type Val-Lys dipeptide. Quantitation of mutant 2207 and the mIL3 producing cell lines was accomplished using $\mathrm{mAb}$ 43D11, an antibody that recognizes an epitope distinct from the site of the 2207 mutation. Serial dilution analysis of mutant 2207 ( Table I) demonstrated that the double mutation reduces the specific activity of murine IL-3 30 -fold.

The next two chimera, gm 6 and gm 1, failed to significantly stimulate colony growth by either human or murine cells, despite the presence of adequate amounts of immunoreac-

Table I. Biological Activity of Chimeric IL-3 Proteins

\begin{tabular}{lccccc}
\hline & \multicolumn{2}{c}{ Activity } & & \multicolumn{2}{c}{ Relative specific activity* } \\
\cline { 2 - 3 } \cline { 5 - 6 } Mutant & Human & Murine & & Human & Murine \\
\hline \multicolumn{3}{c}{$U / m l$} \\
gIL3 & $6.6 \times 10^{4}$ & 0 & & $(1)$ & 0 \\
gm 9 & $6.0 \times 10^{4}$ & 0 & & $1.4 \times 10^{-1}$ & 0 \\
gm 1 & $1.2 \times 10^{2}$ & 0 & & $5.0 \times 10^{-4}$ & 0 \\
gm 6 & $1.4 \times 10^{1}$ & 0 & & $3.0 \times 10^{-4}$ & 0 \\
gm 2 & 0 & $2.2 \times 10^{1}$ & & $7.0 \times 10^{-4}$ \\
gm 3 & 0 & $3.1 \times 10^{4}$ & & 0 & $1.7 \times 10^{-1}$ \\
mIL3 & 0 & $3.8 \times 10^{4}$ & & 0 & $(1)$ \\
2207 & 0 & $1.0 \times 10^{3}$ & & 0 & $3.3 \times 10^{-2}$ \\
& & & &
\end{tabular}

Each protein was simultaneously analyzed by human and murine marrow colony-forming assay and by quantitative Western blotting. The activity results represent the mean of at least four experiments. The data derived from Fig. 2 was used to calculate the amount of gIL3 and the relative amounts of the chimera. The specific activity of gIL3 was calculated to be $8 \times 10^{6} \mathrm{U} / \mathrm{mg}$. The relative amounts of mIL3 and mutant 2207 was determined by phosporimaging of the blot shown in Fig. $4 C$ using a primary antibody (43D11), which recognizes an epitope distinct from the site of the 2207 , gm 3, and gm 2 mutations. The colony-stimulating activity present in the conditioned medium from BHK-derived cell lines is expressed in $\mathrm{U} / \mathrm{ml}$ ( $50 \mathrm{U}=$ amount necessary to stimulate half-maximal colony formation from $10^{5}$ low-density nonadherent human marrow cells or 7.5 $\times 10^{4}$ whole murine marrow cells. ${ }^{*}$ Compared to native human or murine IL-3. 
tive protein (Fig. 2). In contrast, gm 9, which differs from gm 1 at only six positions (between residues $F_{107}$ through $E_{119}$ ), was nearly fully active using human marrow progenitor cells (Table I). The six-amino acid differences between gm 9 (on the left) and gm 1 (on the right) are shown in bold type: ... . F $_{107}$ RRKLKFYLKTLE ${ }_{119}$ DLE . . . to . . . $F_{101}$ RKKLRFY MVHLN ${ }_{113}$ DLE. Thus, two regions, between human IL-3 residues $\mathrm{Val}_{14}$ and $\mathrm{Asp}_{21}$ and between $\mathrm{Phe}_{107}$ and $\mathrm{Glu}{ }_{119}$, were necessary for the proliferative activity of the growth factor.

Receptor binding activity of the chimeric proteins. Receptor binding assays were performed using the human erythroleukemia cell line OCIM1 and the murine factor-dependent cell line FDCP1. These cells display high affinity receptors for human and murine IL-3, respectively. As shown in Table II, chimeric proteins that contain at least the amino-terminal 45 residues of gibbon IL-3 were able to compete with human IL-3 for binding to the IL-3 receptor on OCIM1 cells. Chimeric molecules that contain at least the 124 carboxy-terminal residues of the murine protein (residues 16-140) could compete for binding of ${ }^{125}$ I-murine IL-3 to FDCP1 cells. These data suggest that some of the same residues identified by the colony-forming assays were required for receptor binding. In addition, these data imply that molecules (e.g., gm 6) that fail to stimulate a biologic response are capable, albeit with reduced affinity, of binding to the IL-3 receptor. To be certain that these findings were not caused by differences between the human and gibbon growth factors, we adapted an in vitro translation system to produce radioactively pure gibbon IL-3. Metabolically ${ }^{35} \mathrm{~S}$-labeled proteins were then tested in the receptor binding assay. Using ${ }^{35}$ S-gibbon IL-3, OCIM1 cells were found to display 470 receptors per cell with a $K_{d}$ of 52 pM (Fig. 3). These results for receptor binding avidity compare favorably with that using ${ }^{125}$ I-human IL-3 ( 170 receptors per cell, $K_{d} 63 \mathrm{pM}$ ) and suggest that the gibbon and human molecules interact identically with the human IL-3 receptor. The discrepancy between receptor number identified by human and gibbon IL-3 likely relates to

Table II. IL-3 Receptor Competition Assay

\begin{tabular}{ccc}
\hline & \multicolumn{2}{c}{ Percent specific competition } \\
\cline { 2 - 3 } Protein/mutant & Human & Murine \\
\hline hIL3 & $(100)$ & 0 \\
gIL3 & 80 & 0 \\
gm 9 & 33 & ND \\
gm 1 & 44 & ND \\
gm 6 & 51 & 11 \\
gm 6* & 81 & ND \\
gm 2 & 0 & 17 \\
gm 3 & 17 & 98 \\
mIL3 & ND & $(100)$
\end{tabular}

Concentrated culture media conditioned by BHK-derived cell lines which secrete the gibbon-murine chimeric IL-3 proteins were tested in an OCIM1 or FDCP1 IL-3 receptor competition assay. The results are expressed as the percentage of competition induced by each chimeric protein. Each supernatant was adjusted to contain $3 \mu \mathrm{g}$ of specific protein as determined by quantitative Western blotting (Fig. 4). * In one experiment, $19 \mu \mathrm{g}$ of $\mathrm{gm} 6$ protein was tested. The data represent the mean results of two experiments performed in triplicate. $\mathrm{ND}$, not determined.
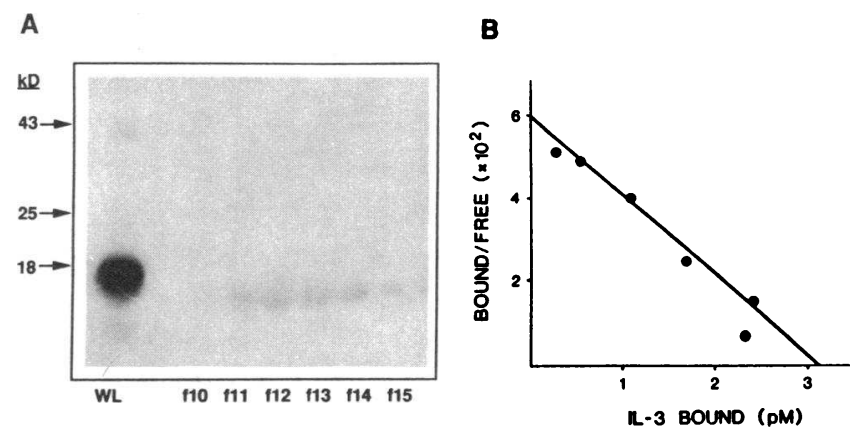

Figure 3. IL-3 receptor binding assay. $(A){ }^{35}$ S-gibbon IL-3, labeled with $\left[{ }^{35} \mathrm{~S}\right] \mathrm{Met}$ in a reticulocyte lysate ( $\mathrm{WL}=$ whole lysate), was separated from unincorporated $\left[{ }^{35} \mathrm{~S}\right] \mathrm{Met}$ by gel filtration. Fractions $11-$ 14 were pooled for use in receptor binding analysis. $(B)$ Scatchard analysis of ${ }^{35} \mathrm{~S}$-labeled gibbon IL-3 binding to OCIM1 cells. OCIM1 cells $\left(0.4 \times 10^{6}\right)$ were incubated with varying quantities of ${ }^{35} \mathrm{~S}$-gibbon IL-3. The data represent the average of duplicate determinations, and were analyzed using the LIGAND program (31).

the use of different preparations of OCIM1 cells for the two experiments.

Mapping the binding epitopes of anti-IL-3 monoclonal antibodies. A series of five distinct anti-human IL-3 and three distinct anti-murine IL-3 mAbs were raised against the recombinant proteins. In addition, antipeptide $\mathrm{mAbs}$ raised against residues 56-74 of human IL-3 and against residues 56-70 of murine IL-3 were also available for analysis. The capacity of these mAbs to recognize denatured human or murine IL-3 in a Western blot format is shown in Fig. 4. To be certain that the IL-3 proteins were completely denatured on the nitrocellulose, the blots were treated with $\mathrm{NaDodSO}_{4}$ and $\beta$-mercaptoethanol and were acetylated after transfer. The strong signal for each $\mathrm{mAb}$ strongly suggests that each antibody recognizes a discrete, short linear array of IL-3-specific amino acids.

Next, several of the mAbs were used to detect the chimeric IL-3 proteins by Western blot analysis. The results from two informative experiments are shown (Fig. 4, $B$ and $C$ ). Based on the differential capacity of mAb 4.4.7 to recognize chimera gm 2 and gm 3, the binding epitope of this antibody must include residues between $\mathrm{Val}_{14}$ and $\mathrm{Asp}_{21}$. Since this $\mathrm{mAb}$ is not conformation dependent, it is likely that this site encompasses most or all of the 4.4.7 binding site. Furthermore, as this mAb (and an Fab fragment derived from it, data not shown) blocks binding of human IL-3 to its receptor on OCIM1 cells (Table III), this site likely comprises at least part of the receptor binding domain of the growth factor. From similar considerations, the differential reaction of the anti-murine IL-3 mAb 43D1 1 with chimera gm 2 and gm 6 suggests that this antibody binds to murine IL-3 between residues $\mathrm{Val}_{21}$ (corresponding to human IL-3 $\mathrm{Ile}_{20}$ ) and $\mathrm{Pro}_{40}$ (corresponding to human IL-3 $\mathrm{Gln}_{45}$ ). Furthermore, as 43D11 neutralizes the biological activity of murine IL-3 (33), this region is also involved in the interaction between IL-3 and its receptor.

To expand upon the Western blotting results and to be certain that the mAbs used in this study recognize IL-3 under physiologic conditions, we next prepared ${ }^{35}$ S-labeled IL-3 proteins and performed immunoprecipitation analyses. Fig. 5 shows the results obtained using several of the anti-human and anti-murine IL-3 mAbs. Based on their precipitation of chimera gm 6 but failure to recognize gm 2, mAbs 6G8, 1F9, and 
A

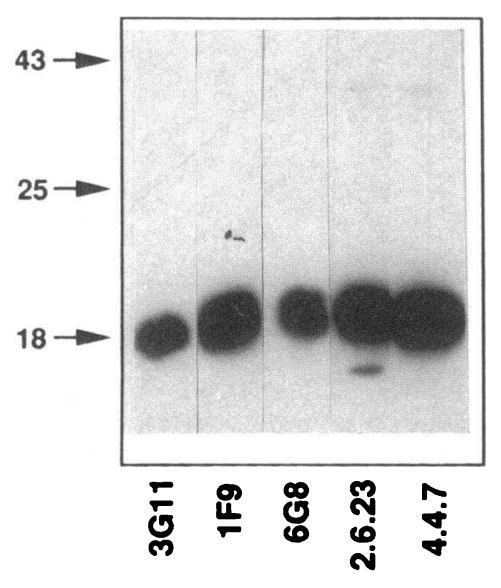

B

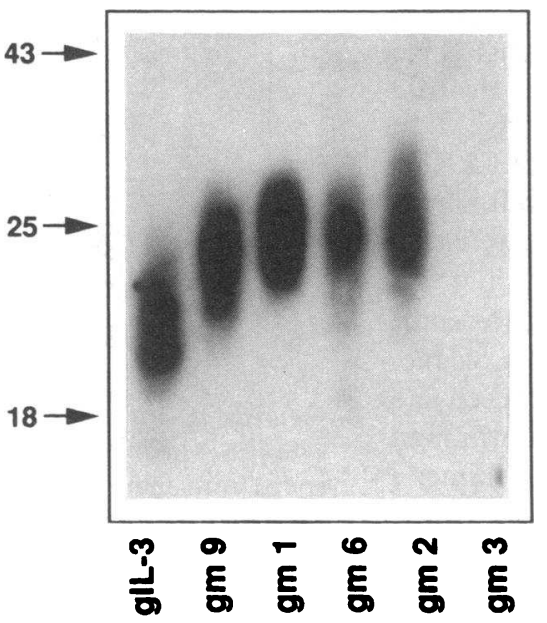

C

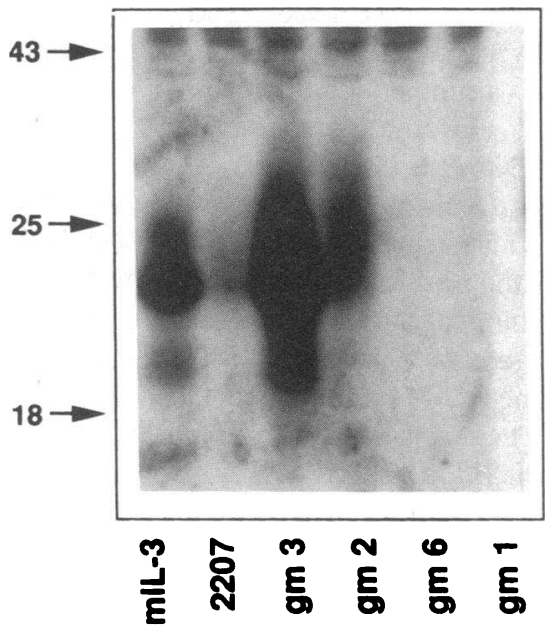

Figure 4. Western blot analyses. Recombinant human IL-3 produced in $E$. coli ( $100 \mathrm{ng})(A)$, or conditioned medium (60 $\mu$ l) from cells expressing gibbon IL-3 (gIL3), murine IL-3 (mIL3), or the IL-3 chimera ( $B$ and $C$ ) were denatured in $\mathrm{NaDodSO}_{4}$ and size-fractionated through $12 \%$ polyacrylamide gels. After electrotransfer to nitrocellulose, the blots were probed with the five anti-human IL-3 mAbs $(A), \mathrm{mAb} 4.4 .7$ $(B)$, and with mAb 43D11 $(C)$. Molecular mass markers are shown $(\mathrm{kD})$ on the left.

2.6.23 were mapped to residues between $\mathrm{Asp}_{21}$ and $\mathrm{Gln}_{45}$. Thus, these antibodies recognize an epitope quite similar to the anti-murine IL-3 mAb 43D11. Since 6G8, 1F9, and 2.6.23 also block binding of human IL-3 to OCIM1 cells ( Table III), these results also point to the importance of this region in the interaction between human IL-3 and its receptor.

Like anti-human mAb 4.4.7, anti-murine mAbs 8F8 and $19 B 3$ recognized residues between $\mathrm{Leu}_{15}$ (human $\mathrm{Val}_{14}$ ) and $\operatorname{Lys}_{22}$ (human $\mathrm{Asp}_{21}$ ). Both of these mAbs neutralized murine IL-3 (33), again confirming the importance of this region for receptor binding and again, demonstrating the concordance of the structural organization of human and murine IL-3.

A third, central epitope was defined by the antipeptide antibodies $8 \mathrm{~A} 5$ and 10F4. These mAbs recognize human residues 56-74 and murine residues 56-70, and are bound to native IL-3, as judged by their ability to immunoprecipitate the mole-

Table III. Receptor Blocking Capacity of Anti-IL-3 Antibodies

\begin{tabular}{lc}
\hline Addition & Competition \\
\hline & $\%$ \\
Saline & 0 \\
$50 \times$ hIL3 & $(100)$ \\
4.4 .7 & 104 \\
2.6 .23 & 132 \\
$3 G 11$ & 187 \\
1F9 & 92 \\
$6 G 8$ & 125 \\
2.1 .3 & 0 \\
\hline
\end{tabular}

\footnotetext{
${ }^{125}$ I-labeled human IL-3 (hIL3) was added to OCIM1 cells in the presence of each of the anti-human IL-3 mAb. The percentage of competition compared to a 50-fold excess of unlabeled human IL-3 is reported. In this experiment, $55 \%$ of the bound cpm could be competed with the unlabeled IL-3, and the experiment has been repeated twice with similar results. mAb 2.1.3 was raised against human GM-CSF and used as a negative control.
}

cule from physiologic solution (Fig. 5). However, they did not neutralize the biological activity of human or murine IL-3 (35). Thus, these mAbs define a central domain not essential for the biological function of IL-3.

The fourth epitope defined in this study includes human residues $\mathrm{Phe}_{107}$ through $\mathrm{Glu}_{119}$, and is recognized by the antihuman IL-3 mAb 3G1 1 (Fig. $5 \mathrm{C}$ ). Again, as 3G11 recognized denatured IL-3 in a Western blot format (Fig. $4 \mathrm{~A}$ ), these residues likely encompass most, if not all of its binding epitope. And, as 3G11 blocks binding of human IL-3 to its receptor (Table III), as does an $\mathrm{F}_{\mathrm{ab}}$ fragment derived from it (data not shown), this result also defines residues that interact with the IL-3 receptor. A summary of the mAb mapping studies using the interspecies chimera is presented in Fig. 6.

Cross-reactivity of anti-IL-3 $\mathrm{mAb}$. To confirm the assignment of epitope regions using the interspecies chimeric proteins, several pairs of mAbs were tested in an ELISA format. For the most part, pairs of mAbs that were assigned to nonoverlapping regions of IL-3 would simultaneously bind to IL-3 in this assay (e.g., 3G11 / 1F9 pair, Fig. 7). However, one unexpected finding was the failure of $6 \mathrm{G8}$ and $3 \mathrm{G} 11$ to simultaneously bind to human IL-3. Two conclusions derive from these findings. First, although 6G8 and 1F9 bind to the same panel of IL-3 chimera, they apparently recognize subtly different epitopes. And second, the failure of 6G8 and 3G11 to simultaneously bind to IL-3 suggests that the epitopes for these two mAbs may reside in close juxtaposition in the tertiary structure of the molecule.

Secondary structural analysis of IL-3. Finally, to begin to correlate the functional domains of IL-3 with its structure, a secondary structure prediction of human IL- 3 based on several different computer algorithms was performed and is shown in Fig. 8. Taken together, these algorithms point to the presence of four helixes. Using the Chou and Fasman predictions, (that residues $17-29,41-51,57-78$, and $103-125$ of human IL-3 are $\alpha$ helixes) and the algorithm of Edmunson, the first and fourth predicted helixes are highly amphipathic; i.e., contain both hy- 

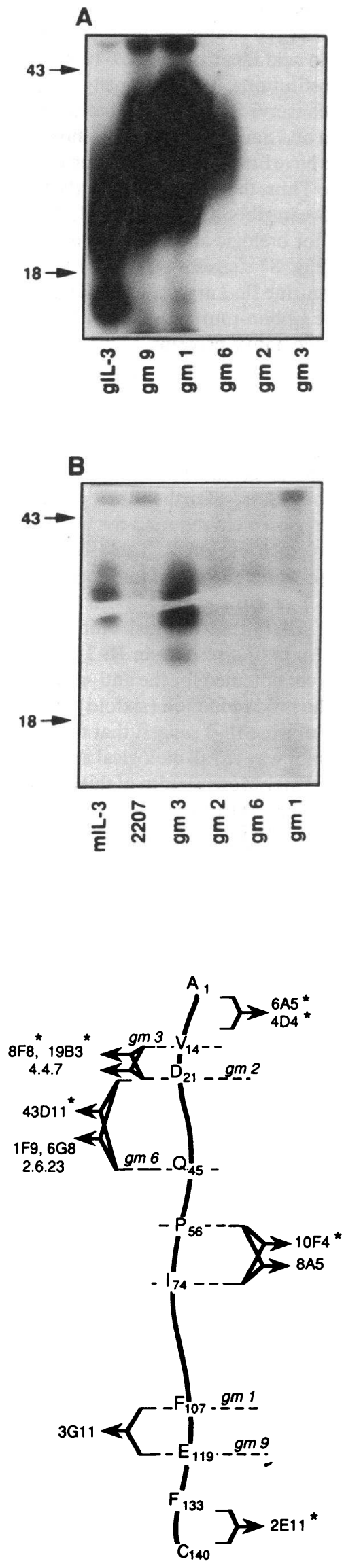
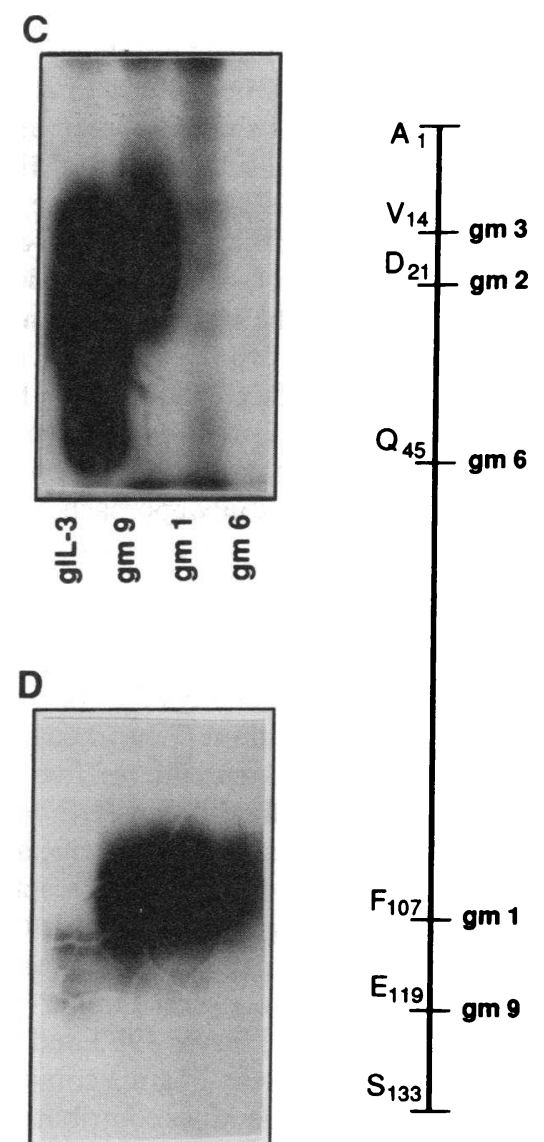

Figure 5. Immunoprecipitation analysis. Conditioned medium ( $1 \mathrm{ml}$ ) from BHK-derived cell lines which produced the IL- 3 chimera were immunoprecipitated with $10 \mu \mathrm{g}$ of a number of anti-IL-3 mAbs $(A=6 \mathrm{G} 8$, $B=8 \mathrm{~F} 8, C=3 \mathrm{G} 11, D=8 \mathrm{~A} 5$ ). The precipitates were size-fractionated by $\mathrm{NaDodSO}_{4}$ polyacrylamide gels, dried, and exposed to film for 2-8 d. Molecular mass markers (kD) are shown. Negative immunoprecipitations were always run with a known positive antibody as control. Each $\mathrm{mAb}$ was used in at least three separate experiments for each chimeric protein with similar results. The line map to the right demonstrates the sites of crossover between gibbon IL-3 sequence above and murine IL-3 sequence below for each chimeric molecule. The single letter amino acid code for the gibbon IL-3 residues is shown at each site.
Figure 6. Binding epitope analysis. The amino acid sequence of human IL-3 is depicted along with a map of the cross-over points of the IL-3 chimera used in this study. The binding epitopes of the receptor blocking and neutralizing $\mathrm{mAb}$ are shown to the left, non-receptor blocking antibodies to the right of the map. *Anti-murine IL-3 antibodies. Data on the sites of 6A5, 4D4, and 2E11 are from Conlon et al. and Ziltener et al. (50-52). drophobic and hydrophilic faces (Fig. 8, $B$ and $C$ ). Next, the sequences of human and murine IL-3 in these regions were compared. As shown, the human and murine IL-3 sequences differ primarily on the hydrophilic faces. Strong sequence conservation is present only for the (presumably) structurally important hydrophobic residues in these helixes. Of note, the two regions identified as critical for receptor binding, biological activity, and for the binding of neutralizing mAbs are located on the first and fourth predicted $\alpha$ helixes.

\section{Discussion}

IL-3 is produced by activated T-lymphocytes in response to antigenic stimulation. The importance of IL-3 in physiologic and in a growing number of pathologic states is becoming increasingly clear. And recently, recombinant human IL-3 has been used to stimulate hematopoietic recovery in states of marrow failure. In this study, the structure-function relationships of this cytokine have been explored. We report that two regions of the molecule, widely separated in the primary amino acid sequence, are required for the biologic activity of IL-3. This conclusion is based on two types of analyses: on the receptor binding and biological activity of chimera of the growth 


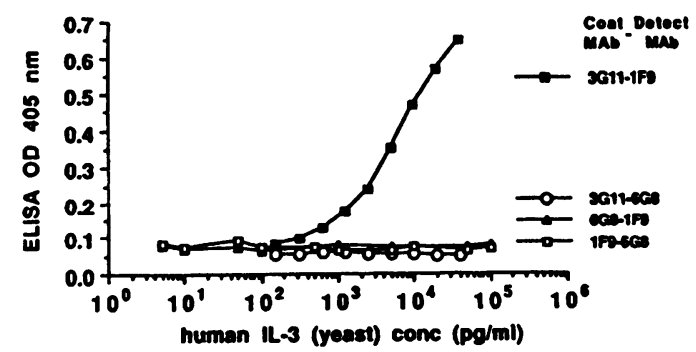

Figure 7. Immunoenzymetric assay format to detect monoclonal antibody pairs recognizing spatially distinct epitopes on IL-3. The 3G11 coating antibody and the 1F9 detecting antibody pair uniquely provides a sensitive two-site sandwich immunoassay for human IL-3. The other combinations effectively crossblock implying recognition of spatially overlapping epitopes.

factor and on the location of the binding epitopes of a series of neutralizing and nonneutralizing $\mathrm{mAb}$ that recognize human or murine IL-3.

Using a series of gibbon-murine chimeric IL-3 molecules, we found that residues in both the amino-terminal half and carboxy-terminal half of the growth factor were required for full biologic activity. This approach to structure-function analysis is based on the assumption that receptor interactive sites of a protein can be identified by substituting regions not critical for receptor binding with homologous domains of structural similarity. In this way the limitations of deletion analysis (in which removal of structurally important but receptor-irrelevant residues cannot be distinguished from elimination of sites of receptor interaction) are overcome. We have recently used this approach to map the receptor-interactive residues of the functionally related cytokine, GM-CSF (21), results of which were supported by crystallographic analysis of the growth factor, once it became available (45). Other successful applications of this approach include mapping of the receptor binding site of $\alpha$-interferons (46) and the binding site of the HIV virus on the T cell CD4 molecule (47). Recently, Chothia and co-workers have shown that if two proteins share as little as $20 \%$ primary amino acid homology, their tertiary structures are quite similar (48). In addition to $26 \%$ amino acid identity and $40 \%$ homology based on conservative substitutions, the biologically critical disulfide bond of IL-3 is conserved throughout evolution $(18,25)$. Furthermore, Pakula and Sauer have recently shown that surface side chain changes have little impact on the tertiary structure of polypeptides (49). Thus, the finding that nearly all of the amino acid changes between gibbon and murine IL-3 in the two regions found critical for biologic activity occur at the surface of the growth factor (Fig. 8) suggests that the tertiary conformation of gibbon and murine IL-3 are quite similar and that the folded structure of the gibbon-murine hybrids used in this study approaches that of the native proteins.

In the amino-terminal region, murine IL-3 residues Leu $_{15}$ through $\mathrm{Lys}_{22}$ (corresponding to gibbon residues $\mathrm{Val}_{14}$ through $A \mathrm{sp}_{21}$ ) appear to be critical for colony-stimulating activity. This was best exemplified by comparing the colony-stimulating activity of mutants gm 3 and gm 2, which differ only in five positions $\left(\mathrm{Leu}_{15}\right.$ and $\mathrm{Ser}_{19}$ through $\mathrm{Lys}_{22}$. Furthermore, gibbon IL-3-specific residues in this region were required for binding to the human IL-3 receptor (gm 6 vs. gm 2, Table II) and murine IL-3-specific amino acids were required for binding to the murine IL-3 receptor ( $\mathrm{gm} 3 \mathrm{vs.} \mathrm{gm} \mathrm{2}$ ). In addition, the $F_{\mathrm{ab}}$ fragment of a mAb (termed 4.4.7) that blocked binding of human IL-3 to its receptor also bound to human IL-3 in this same region. Similar results were obtained for the anti-murine IL-3 mAbs 19B3 and 8F8. The mild reduction (sixfold) in the activity of gm 3 compared to murine IL-3 suggest that the first 15 residues contribute in a minor way to full biological activity.

Additional residues immediately downstream of this region also appear to be involved in receptor binding. The anti-human IL-3 mAbs 6G8, 2.6.23, and 1F9, and the anti-murine IL-3 mAb 43D11 recognize a closely contiguous epitope, located between human $\mathrm{Asp}_{21}$ and $\mathrm{Gln}_{45}$ (murine $\mathrm{Lys}_{22}$ and Pro $_{40}$ ). All of these mAbs block binding to the IL-3 receptor and neutralize the biological activity of the growth factor. In addition, together with two other reports $(19,20)$, this study
A

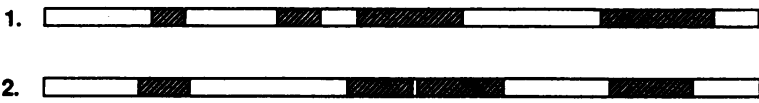

2.

3.

4.

B

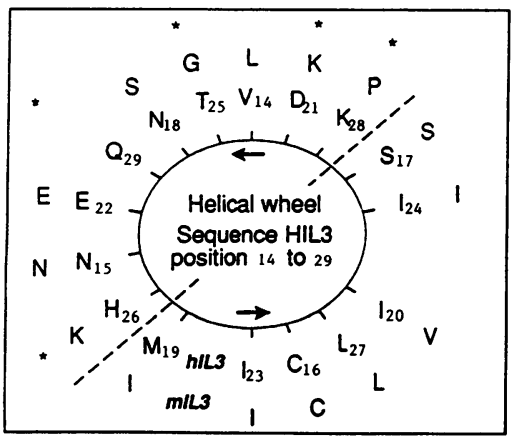

C

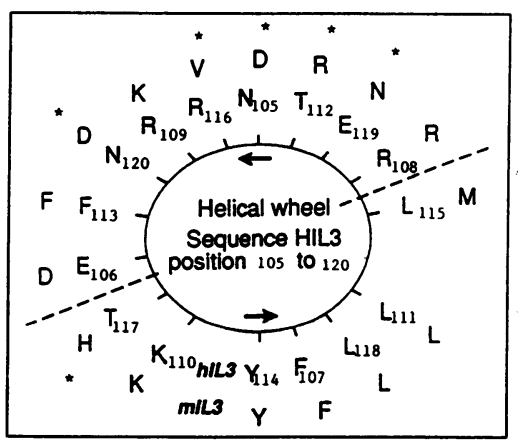

Figure 8. Secondary structure predictions of IL-3. $(A)$ The algorithms of 1) Garnier (41), 2) Parry (42), 3) Chou and Fasman (43), and 4) Gascuel (44) were applied to the amino acid sequence of human IL-3. The predictions of Chou and Fasman were next utilized to determine the characteristics of each helix. The first $(B)$ and fourth $(C)$ helixes are presented in Edmunson projection. The sequences of human (hIL3) and murine IL-3 (mIL3) are depicted. *Nonconserved amino acids. 
brings to 16 the number of neutralizing mAbs that have been mapped to residues between $A \mathrm{Ap}_{21}$ and $\mathrm{Gln}_{50}$. Thus, this region is highly immunogenic and easily accessible for protein-protein interaction.

Three of the four secondary structural algorithms applied to the primary structures of human IL-3 predict that this critical amino-terminal region is likely to assume an $\alpha$-helical conformation in solution. Examination of the helix in the Edmunson projection reveals that of the five residues altered between gm 3 and gm 2, three are surface-oriented and two are buried in the hydrophobic core of the protein. As the two hydrophobic changes are relatively conservative (murine IL-3 Ile $_{20}$ to Met, $\mathrm{Val}_{21}$ to Ile), the surface changes likely represent critical receptor interactive residues. This was confirmed in part by the substantially reduced activity of mutant 2207 (murine $\mathrm{Val}_{21}-\mathrm{Lys}_{22}$ to human $\mathrm{Ile}_{20}-\mathrm{Asp}_{21}$ ). However, although this amino-terminal region is important for receptor binding, it is not sufficient for biological activity. The substantial loss of function of chimera gm 6 and gm 1 is likely attributed to dissociation of these residues and additional critical regions of IL-3, and not caused by gross alterations in structural integrity. Strong support for this latter conclusion is provided by the hybrid gm 6, a molecule capable of binding to the IL-3 receptor despite a reduction in biological activity by four orders of magnitude.

The second region of IL-3 required for biological activity mapped to residues between human IL-3 $\mathrm{Phe}_{107}$ and $\mathrm{Glu}_{119}$. This conclusion is based on the differential activity of the gm 9 and gm 1 chimera. Furthermore, like the amino-terminal domain, this region also binds the $F_{a b}$ fragment of a neutralizing $\mathrm{mAb}, 3 \mathrm{G} 11$. And, like the amino-terminal functional domain, this region is also predicted to form an amphiphilic $\alpha$ helix. Examination of the gibbon-murine homology in this helix is even more striking for hydrophilic substitutions and hydrophobic conservation. Again, these findings strongly suggest that the hydrophilic amino acid residues in this region are responsible, along with those of the first helix, for the species-specific activity of IL-3 and, by extrapolation, for the biologic activity of the growth factor.

Besides the two regions required for receptor binding and biological activity, the present study and two previous studies have demonstrated that the extreme amino-terminal and extreme carboxy-terminal regions of murine IL-3, as well as the central domain defined by the antipeptide mAbs $8 \mathrm{~A} 5$ and 10F4, are dispensable for biological activity. Conlon and coworkers, and Ziltener et al. have reported independently on two $\mathrm{mAbs}$ directed against the six amino-terminal residues of murine IL-3 $(50,51)$. These antibodies failed to neutralize IL-3 bioactivity. Ziltener and colleagues have also described two mAbs that mapped very closely to the carboxy terminus of murine IL-3, residues $\operatorname{Ser}_{130}$ through $\operatorname{Arg}_{135}$ (52). Neither of these mAbs neutralized the bioactivity of IL-3 in vitro. Taken together, the present and previous studies of anti-IL-3 mAbs and antisera point to the presence of several neutralizing epitopes that cluster into two regions, surrounded by three epitopes which bind to regions of IL-3 apparently not immediately involved in receptor interaction.

To confirm the binding site assignments based on the Western blot and immunoprecipitation analyses, many of the mAbs were tested in pairs in a sandwich ELISA. As expected, mAbs 6G8 and 1F9, which appeared to recognize identical epitopes in the immunoprecipitation analysis, failed to simultaneously bind to human IL-3 in the ELISA (Fig. 7). Surprisingly, however, although 1F9 bound to human IL-3 in the presence of 3G11, 6G8 failed to bind to IL-3 in the presence of 3G11. Two conclusions derive from these findings. First, 1F9 and 6G8 must recognize subtly different epitopes within the region between $\mathrm{Asp}_{21}$ and $\mathrm{Gln}_{45}$; and second, the binding epitopes of 6G8 and $3 \mathrm{G} 11$, which are widely separated in the primary amino acid sequence of human IL-3 $\left(A s_{21}\right.$ to $\operatorname{Gln}_{45}$ and $P_{h} e_{107}$ to $\mathrm{Glu}_{119}$, respectively), likely reside in close juxtaposition in the tertiary structure of the molecule. This latter conclusion is quite similar to the findings reported in analyses of GM-CSF, IL-2, and IL-6 $(39,53-55)$. And like the findings reported herein for IL-3, the active receptor binding sites of these cytokines are also composed of amphipathic helixes.

Finally, the ability of gm 6 to bind to the IL-3 receptor and its near failure to induce signal transduction points to the importance of the fourth predicted helix in this latter process. The carboxy-terminal domain may act to induce a proliferative stimulus in responding cells by binding to a signal-transducing region of the IL-3 receptor, by causing receptor internalization, by inducing a conformational change in the receptor, or by other mechanisms. Additional studies will be required to determine the precise mechanism of this effect. However, the capacity to dissociate receptor binding and signal transduction may find clinical utility as an IL-3 antagonist. The importance of IL-3 in a number of pathologic processes, including hypersensitivity reactions (4) and leukemogenesis $(6,7)$, suggest that alternative therapies based on the principles of rationale drug design may be forthcoming.

\section{Acknowledgments}

The authors wish to thank Zenaida Sisk for preparation of the manuscript, Steven Clark for the gibbon IL-3 cDNA, Frank Lee for the murine IL-3 cDNA, Thalia Papayannopoulou for the OCIM1 cell line, Margot Gibson for assistance with phosphorimaging, and Gerry Krystal for the ${ }^{125} \mathrm{I} \mathrm{mIL}-3$.

\section{References}

1. Kobayashi, M., B. H. Van Leeuwen, S. Elsbury, M. E. Martinson, I. G. Young, and A. J. Hapel. 1989. Interleukin-3 is significantly more effective than other colony-stimulating factors in long-term maintenance of human bone marrow derived colony forming cells in vitro. Blood. 73:1836-1841.

2. Bot, F. J., L. van Eijk, P. Schipper, and B. Lowenberg. 1989. Effects of human interleukin-3 on granulocytic colony-forming cells in human bone marrow. Blood. 73:1157-1160.

3. Rothenberg, M. E., W. F. Owen, D. S. Silberstein, J. Woods, R. J. Soberman, K. F. Austen, and R. L. Stevens. 1988. Human eosinophils have prolonged survival, enhanced functional properties, and become hypodense when exposed to human interleukin 3. J. Clin. Invest. 81:1986-1992.

4. Kita, H., O. Tsukasa, Y. Okubo, D. Weiler, J. S. Abrams, and G. J. Gleich. 1991. Granulocyte/macrophage colony-stimulating factor and interleukin 3 release from human peripheral blood eosinophils and neutrophils. J. Exp. Med. 174:745-748.

5. Valent, P., K. Geissler, C. Sillaber, K. Lechner, and P. Bettelheim. 1990. Why clinicians should be interested in Interleukin-3. Blut. 61:338-345.

6. Ihle, J., K. Morishita, D. Parker, C. Bartholomew, D. Askew, A. Buchberg, N. Jenkins, N. Copeland, and Y. Weinstein. 1989. Mechanisms in transformation of IL3-dependent hematopoietic stem cells. Microbiol. Immunol. 149:59-69.

7. Grimaldi, J. C., and T. C. Meeker. 1989. The t (5;14) Chromosomal translocation in a case of acute lymphocytic leukemia joins the interleukin-3 gene to the immunoglobulin heavy chain gene. Blood. 73:2081-2085.

8. Park, L. S., P. E. Waldron, D. Friend, H. M. Sassenfeld, V. Price, D. Anderson, D. Cosman, R. G. Andrews, I. D. Bernstein, and D. L. Urdal. 1989. Interleukin-3, GM-CSF, and G-CSF receptor expression on cell lines and primary leukemia cells: Receptor heterogeneity and relationship to growth factor responsiveness. Blood. 74:56-65. 
9. Park, L. S., D. Friend, V. Price, D. Anderson, J. Singer, K. S. Prickett, and D. Urdal. 1989. Heterogeneity of human interleukin-3 receptors. J. Biol. Chem. 264:5420-5427.

10. Itoh, N., S. Yonehara, J. Schreurs, D. Gorman, K. Maruyama, A. Ishii, I. Yahara, K-I. Arai, and A. Miyajima. 1990. Cloning of an interleukin-3 receptor gene: a member of a distinct receptor gene family. Science (Wash. DC). 247:324327.

11. Kitamura, T., N. Sato, K. Arai, and A. Miyajima. 1991. Expression cloning of the human IL-3 receptor cDNA reveals a shared $\beta$ subunit for the human IL-3 and GM-CSF receptors. Cell. 66:1165-1174.

12. Bazan, J. F. 1990. Structural design and molecular evolution of a cytokine receptor superfamily. Proc. Natl. Acad. Sci. USA. 87:6934-6938.

13. Budel, L., O. Elbaz, H. Hoogerbrugge, R. Delwel, L. Mahmoud, B. Lowenberg, and I. Touw. 1990. Common binding structure for granulocyte macrophage colony stimulating factor and interleukin 3 on human myeloid leukemia cells and monocytes. Blood. 75:1439-1445.

14. Hayashida, K., T. Kitamura, D. M. Gorman, K. Arai, T. Yokota, and A. Miyajima. 1990. Molecular cloning of a second subunit of the receptor for human granulocyte-macrophage colony-stimulating factor (GM-CSF): reconstitution of a high affinity GM-CSF receptor. Proc. Natl. Acad. Sci. USA. 87:9655.

15. Taketazu, F., S. Chiba, K. Shibuya, T. Kuwaki, H. Tsumura, K. Miyazono, K. Miyagawa, and F. Takaku. 1991. IL-3 specifically inhibits GM-CSF binding to higher affinity receptor. J. Cell. Physiol. 146:251-257.

16. Lopez, A., J. Eglinton, D. Gillis, L. Park, S. Clark, and M. Vadas. 1989. Reciprocal inhibition of binding between interleukin 3 and granulocyte-macrophage colony-stimulating factor to human eosinophils. Proc. Natl. Acad. Sci. USA. 86:7022-7026.

17. Clark-Lewis, I., R. Aebersold, H. Ziltener, J. Schrader, L. Hood, and S. Kent. 1986. Automated chemical synthesis of a protein growth factor for hemopoietic cells, interleukin-3. Science (Wash. DC). 231:134-139.

18. Clark-Lewis, I., L. Hood, and S. Kent. 1988. Role of disulfide bridges in determining the biological activity of interleukin 3. Proc. Natl. Acad. Sci. USA. 85:7897-7901.

19. Dorssers, L. C. J., M. C. Mostert, H. Burger, C. Janssen, P. J. Lemson, R. van Lambalgen, G. Wagemaker, and R. W. van Leen. 1991. Receptor and antibody interactions of human interleukin- 3 characterized by mutational analysis. J. Biol. Chem. 266:21310-21317.

20. Lokker, N. A., U. Strittmatter, C. Steiner, B. Fagg, P. Graff, H. P. Kocher, and G. Zenke. 1991. Mapping the epitopes of neutralizing anti-human IL-3 monoclonal antibodies. J. Immunol. 146:893-898.

21. Kaushansky, K., S. Shoemaker, S. Alfaro, and C. Brown. 1989. The hematopoietic activity of granulocyte-macrophage colony-stimulating factor is dependent upon two distinct regions of the molecule: a functional analysis based upon the activities of hybrid growth factors. Proc. Natl. Acad. Sci. USA. 86:1213-1217.

22. Kaushansky, K., P. O'Hara, C. Hart, J. Forstrom, and F. Hagen. 1987. Role of carbohydrate in the function of human granulocyte-macrophage colonystimulating factor. Biochemistry. 26:4861-4867.

23. Sanger, F., S. Nicklen, and A. R. Coulson. 1977. DNA sequencing with chain-terminating inhibitors. Proc. Natl. Acad. Sci. USA. 74:5463-5467.

24. Berkner, K., S. Busky, E. Davie, C. Hart, M. Insley, W. Kiesel, A. Kumar, M. Murray, P. O'Hara, R. Woodburg, and F. Hagen. 1986. Isolation/expression of cDNAs encoding human factor VII. CSH Symposium on Quantitation Biol ogy. 51:531-541.

25. Otsuka, T., A. Miyajima, N. Brown, K. Otsu, J. Abrams, S. Saeland, C Caux, R. de Waal Malefijt, J. de Vries, P. Meyerson, et al. 1988. Isolation and characterization of an expressible cDNA encoding human IL-3. Induction of IL-3 mRNA in human T cell clones. J. Immunol. 140:2288-2295.

26. Hapel, A. J., H. S. Warren, and D. A. Hume. 1984. Different colony-stimulating factors are detected by the interleukin-3 dependent cell lines FDC-P1 and 32D cl-23. Blood. 64:786-790.

27. Papayannopoulou, Th., B. Nakamoto, S. Kurachi, M. Tweeddale, and H. Messner. 1988. Surface antigen profile and globin phenotype of two new human erythroleukemia lines-characterization and interpretations. Blood. 72:10291038

28. Broudy, V. C., N. Lin, J. Egrie, C. de Haen, T. Weiss, Th. Papayannopoulou, and J. W. Adamson. 1988. Identification of the receptor for erythropoietin on human and murine erythroleukemia cells and modulation by phorbol ester and dimethyl sulfoxide. Proc. Natl. Acad. Sci. USA. 85:6513-6517.

29. Murthy, S. C., P. H. B. Sorensen, A. L.-F. Mui, and G. Krystal. 1989. Interleukin-3 down-regulates its own receptor. Blood. 73:1180-1187.

30. Calvo, J. C., J. P. Radicella, and E. H. Charreau. 1983. Measurement of specific radioactivities in labeled hormones by self-displacement analysis. Biochem. J. 212:259-264.

31. Munson, P. J., and D. Rodbard. 1980. LIGAND: a versatile computerized approach for characterization of ligand-binding systems. Anal. Biochem. 107:220-239.
32. Rector, E. S., R. J. Schwenk, K. S. Tse, and A. H. Sehon. 1978. A method for the preparation of protein-protein conjugates of predetermined composition. J. Immunol. Methods. 24:321-336.

33. Abrams, J. S., and M. K. Pearce. 1988. Development of rat anti-mouse interleukin 3 monoclonal antibodies which neutralize bioactivity in vitro. $\mathrm{J}$. Immunol. 140:131-137.

34. Mosmann, T. R., J. S. Abrams, N. Arai, M. W. Bond, F. D. Lee, A Miyajima, S. Miyatake, D. M. Rennick, J. Schreurs, C. A. Smith, et al. 1987. Mouse interleukin-3 recombinant cDNA cloning, expression and characterization. In Recombinant Lymphokines and Their Receptors, Immunology Series 35. S. Gillis, editor. Marcel Dekker, New York, pp. 217-240.

35. Lee, R., J. Abrams, N. Arai, A. Miyajima, S. Miyatake, T. Mosmann, D. Rennick, J. Schreurs, C. Smith, Y. Takabe, et al. 1987. The expression and characterization of recombinant mouse IL-3. Lymphokines. 15:163-182.

36. Mosmann, T. 1983. Rapid colorimetric assay for cellular growth and survival: application to proliferation and cytotoxicity assays. J. Immunol. Meth ods. 65:55-63.

37. Reichlin, M., A. Nisonoff, and E. Margoliash. 1970. Immunological activity of cytochrome C. III. Enhancement of antibody detection and immune response initiation by cytochrome C polymers. J. Biol. Chem. 245:947-954.

38. Kitamura, K., Y-F. Piao, K. Miyazono, A. Urabe, and F. Takaku. 1989. Establishment and characterization of a unique human cell line that proliferates dependently on GM-CSF, IL-3, or erythropoietin. J. Cell. Physiol. 140:323-334.

39. Brown, C. B., C. E. Hart, D. M. Curtis, M. C. Baily, and K. Kaushansky. 1990. The neutralizing monoclonal antibodies against human granulocyte-macrophage colony-stimulating factor recognize the receptor binding domain of the molecule. J. Immunol. 144:2184-2189.

40. Chretien, I., A. Van Kimmenade, M. K. Pearce, J. Banchereau, and J. S. Abrams. 1989. Development of polyclonal and monoclonal antibodies for immunoassay and neutralization of human interleukin-4. J. Immunol. Methods. 117:67-81.

41. Garnier, J. 1978. Analysis of the accuracy and implications of simple methods for predicting the secondary structure of globular proteins. J. Mol. Biol. 120:97-120.

42. Parry, D., E. Minasian, and S. Leach. 1988. Conformational homologies among the cytokines: interleukins and colony-stimulating factors. Molecular Recognition. 1:107-110.

43. Chou, P. Y., and G. D. Fasman. 1978. Prediction of the secondary structure of proteins from their amino acid sequence. Adv. Enzymol. Relat. Areas Mol. Biol. 47:45-148.

44. Gascuel, O., and J. L. Golmard. 1988. A simple method for predicting the secondary structure of globular proteins; implications and accuracy. Comput. Appl. Biosci. 4:357.

45. Diederichs, K., T. Boone, and P. A. Karplus. 1991. Novel fold and putative receptor binding site of granulocyte-macrophage colony-stimulating factor. Science (Wash. DC). 254:1779-1782.

46. Raj, N., R. Israeli, K. Kelley, S. Leach, E. Minasian, K. Sikaris, D. Parry, and P. Petha. 1988. Synthesis, antiviral activity, and conformational characterization of mouse-human alpha-interferon hybrids. J. Biol. Chem. 263:8943-8952.

47. Landau, N. R., M. Warton, and D. R. Littman. 1988. The envelope glycoprotein of the human immunodeficiency virus binds to the immunoglobulin-like domain of CD4. Nature (Lond.). 334:159-162.

48. Chothia, C., and A. M. Lesk. 1986. The relation between the divergence of sequence and structure in proteins. EMBO (Eur. Mol. Biol. Organ.) J. 5:823 826.

49. Pakula, A. A., and R. T. Sauer. 1989. Genetic analysis of protein stability and function. Annu. Rev. Genet. 23:289-310.

50. Conlon, P. J., K. H. Luk, L. S. Park, C. J. March, T. P. Hopp, and D. L. Urdal. 1985. Generation of anti-peptide monoclonal antibodies which recognize mature CSF-2Á (IL 3) protein. J. Immunol. 135:328-332.

51. Ziltener, H., I. Clark-Lewis, B. de St. Groth, L. Hood, S. Kent, and J. Schrader. 1987. Antipeptide antibodies define the $\mathrm{NH}_{2}$-terminal structure of the pan-specific hemopoietin interleukin 3. J. Immunol. 138:1 105-1008.

52. Ziltener, H., I. Clark-Lewis, B. de St. Groth, P. Orban, L. Hood, S. Kent, and J. Schrader. 1988. Monoclonal antipeptide antibodies recognize IL-3 and neutralize its bioactivity in vivo. J. Immunol. 140:1182-1187.

53. Brandhuber, B. J., T. Boone, W. C. Kenney, and D. B. McKay. 1987 Three-dimensional structure of interleukin-2. Science (Wash. DC). 238:17071709.

54. Brakenhoff, J., P. J. M. Hart, and L. A. Aarden. 1989. Analysis of human IL-6 mutants expressed in Escherichia coli biologic activities are not affected by deletion of amino acids 1-28. J. Immunol. 143:1175-1182.

55. Ida, N., S. Sakurai, T. Hosaka, K. Hosoi, T. Kunitomo, T. Shimazu, T. Maruyama, Y. Matsuura, and M. Kohase. 1989. Establishment of strongly neutralizing monoclonal antibody to human interleukin-6 and its epitope analysis. Biochem. Biophys. Res. Commun. 165:728-734. 